\title{
PERILAKU PERAWAT DALAM PENCEGAHAN INFEKSI NOSOKOMIAL DI RUANG ASOKA 1 RSUD DR.PIRNGADI MEDAN
}

\author{
Dina Yusdiana Dalimunthe \\ Staf Poltekkes Kemenkes Jurusan Keperawatan Medan
}

\begin{abstract}
Abstrak
Rumah sakit sebagai salah satu bagian sistem pelayanan kesehatan secara garis besar memberikan pelayanan kesehatan mencakup pelayanan untuk masyarakat. Adapun rumah sakit juga merupakan salah satu tempat yang paling mungkin mendapat infeksi karena mengandung populasi mikroorganisme. Infeksi nosokomial adalah infeksi yang terjadi di rumah sakit dan menyerang penderita yang sedang dalam proses perawatan. Infeksi nosokomial merupakan masalah yang nyata di seluruh dunia dan terus meningkat secara data $\mathrm{WHO}$ (World Health Organization). Di negara berkembang termasuk Indonesia, rata-rata prevalensi infeksi nosokomial adalah sekitar 9,1\% dengan variasi 6,1\%-16,0\%. Adapun jenis penelitian yang digunakan dalam penelitian ini adalah dekskriptif yang menggambarkan perilaku perawat dalam pencegahan infeksi nosokomial di RSUD Dr. Pirngadi Kota Medan. Desain penelitian cross sectional dimana variabel bebas dan terikat dilakukan pengukuran atau pengamatan pada saat bersamaan.Hasil penelitian menunjukkan bahwa dalam pencegahan infeksi nosokomial yang memiliki pengetahuan cukup adalah sebanyak 16 orang $(53,3 \%)$, sikap positif sebanyak 24 orang $(80 \%)$, tindakan tidak patuh 25 orang $(83,3 \%)$, dan upaya pencegahan tidak baik dan tidak patuh 17 orang $(77,3 \%)$.
\end{abstract}

Kata kunci : Perilaku, Perawat, Infeksi Nosokomial

\section{PENDAHULUAN}

Rumah sakit sebagai salah satu bagian sistem pelayanan kesehatan secara garis besar memberikan pelayanan kesehatan mencakup pelayanan untuk masyarakat. Adapun rumah sakit juga merupakan salah satu tempat yang paling mungkin mendapat infeksi karena mengandung populasi mikroorganisme. Infeksi nosokomial adalah infeksi yang terjadi di rumah sakit dan menyerang penderita yang sedang dalam proses perawatan. Infeksi ini terjadi sesudah 72 jam perawatan pasien rawat inap dan perlu diketahui infeksi nosokomial bukan hanya terjadi kepada pasien tetapi dapat juga terhadap petugas rumah sakit sebagai salah satunya perawat yang dalam sehari-harinya kontak langsung dengan pasien.

Menurut Darmadi (2008) yang dikutip Septiari (2012) perawat sangat berperan penting dalam pencegahan infeksi nosokomial, sebab perawat merupakan praktisi kesehatan yang berhubungan langsung dengan pasien dan bahan infeksi di ruangan perawatan. Rosita (2010) juga mengatakan perawat mampu untuk mencegah penularan infeksi nosokomial dengan prosedur dan cara yang tepat. Salah satu tindakan yang dapat menyebabkan terjadinya infeksi nosokomial adalah dikarenakan perawat yang menggunakan sarung tangan dan lupa menggantinya sewaktu memeriksa pasien lainnya, atau satu bagian ke bagian lainnya. Dengan kejadian di atas maka tindakan pencegahan infeksi nosokomial harus diketahui oleh petugas rumah sakit dan dilaksanakan.

Selain itu para ahli kesehatan Center of Disease and Prevention menetapkan dua bentuk pencegahan yaitu : pencegahan standart, didesain untuk semua perawatan pasien di rumah sakit tanpa memperhatikan diagnosa pasien atau status infeksi sebelumnya. Tindakan pencegahan transmisi yang dibagi dalam katagori udara, droplet dan kontak yang digunakan pada pasien yang diketahui atau dicurigai terinfeksi dapat ditularkan melalui udara dan kontak. Di beberapa bagian, terutama bagian penyakit dalam terdapat banyak prosedur dan tindakan yang dilakukan baik untuk membantu diagnosa maupun memonitor perjalanan penyakit dan terapi yang dapat menyebabkan pasien cukup rentan terkena infeksi nosokomial (Swearing, 2003).

Menurut Wikansari, dkk (2012) Infeksi nosokomial merupakan masalah yang nyata di seluruh dunia dan terus meningkat secara data $W H O$ (World Health Organization). Kejadian infeksi nosokomial berkisar $1 \%$ di beberapa negara Eropa dan Amerika hingga $40 \%$ dibeberapa tempat di Asia bahwa sekitar $8,7 \%$ dari 55 rumah sakit 14 negara yang berasal dari Eropa, Timur Tengah, Asia tenggara, dan Pasifik menunjukkan adanya infeksi nosokomial dimana $10 \%$ diantaranya terjadi di Asia Tenggara. Semakin meningkatnya pasien dengan kasus "immunocompromised" merupakan penyebab banyak kematian akibat infeksi nosokomial hingga 88.000 kasus setiap tahunnya.

Menurut Soeroso (2000) yang kutip oleh Septiari (2010) menyatakan di negara berkembang termasuk Indonesia, rata-rata prevalensi infeksi nosokomial adalah sekitar 9,1\% dengan variasi $6,1 \%$ $16,0 \%$. Kejadian infeksi nosokomial pada jenis/tipe rumah sakit indonesia sangat beragam. Adapun hasil 
penelitian Depkes RI (2004) diperoleh data proporsi kejadian infeksi nosokomial di rumah sakit pemerintah dengan jumlah pasien 1.527 orang dari jumlah pasien beresiko $160.417(55,1 \%)$, sedangkan untuk rumah sakit swasta dengan jumlah pasien 991 pasien dari jumlah pasien beresiko 130.047 (35,7\%), data rumah sakit ABRI dengan jumlah pasien 254 pasien dari jumlah pasien beresiko $1.672(9,1 \%)$.

Sumatera Utara mempunyai komite Pencegahan Pengendalian Infeksi (PPI) rumah sakit. PPI mempunyai kegiatan-kegiatan pencegahan dan pengendalian infeksi nosokomial yang terprogram, program tersebut dapat berupa pelatihan ataupun pengawasan langsung ke ruang-ruang perawatan. Berdasarkan data dari PPI rumah sakit Columbia Asia Medan masih terdapat kejadian infeksi nosokomial sekitar 5\% pada pemasangan dower catheter, $6 \%$ kejadian plebitis skala satu, 1 kasus suspect MRSA pada bulan Agustus 2010, 1 kasus suspect MRSA pada bulan September 2010 dan 1 kasus suspect MRSA pada bulan Oktober 2010 (Rosita, 2010).

Penelitian yang dilakukan oleh Nurseha (2012) data RSUP Prof.Dr.R.D kandau Manado berupa pengembangan tindakan pencegahan infeksi nosokomial oleh perawat di Rumah Sakit Berbasis Health Belief Model menunjukkan bahwa adanya hubungan kerentanan, keparahan infeksi dan manfaat berkolerasi dengan pencegahan infeksi nosokomial (nilai $\mathrm{p}=0,201>0,05$ ).

RSUD Dr Pirngadi Medan adalah rumah sakit pemerintah kota Medan yang berdiri dari tahun 1928 sampai sekarang. RSUD Dr. Pirngadi Medan memiliki ruangan penyakit dalam pria atau ruangan Asoka 1. Ruangan asoka 1 adalah ruangan bangsal dengan kapasitas pasien 40 pasien dan dengan jumlah perawat 30 perawat

Berdasarkan hasil survey pendahuluan peneliti di RSUD Dr Pirngadi Medan data dari rekam medik, RSUD Dr Pirngadi Medan pada tanggal 30 januari 2014, diperoleh 1401 pasien infeksi nosokomial pada tahun 2012, sedangkan pada tahun 2013 sebanyak 1588 pasien di semua ruang inap RSUD Dr Pirngadi Medan, sementara hasil data dari ruang asoka 1 pada tahun 2013 infeksi luka bedah 47 pasien, ISK 23 pasien, pneumonia 21 pasien, plebitis 16 dan akibat pemasangan kateter 33 pasien.

Berdasarkan survey dan bukti rekam medik RSUD Dr. Pirngadi Medan menunjukkan bahwa kejadian infeksi nosokomial semangkin meningkat. Perawat adalah salah satu peran dalam upaya pencegahan infeksi nosokomial. Maka diperlukan perilaku perawat yang mendukung menuju perubahan yang lebih baik. Salah satunya adalah perilaku cuci tangan sebelum dan sesudah melakukan tindakan dan menggunakan 1 sarung tangan untuk 1 pasien sewaktu memeriksa atau melakukan tindakan, perawat merupakan salah satu faktor yang mempunyai pengaruh besar terhadap pencegahan infeksi nosokomial sudah dipahami, tetapi untuk prakteknya sulit dilakukan hal ini kemungkinan karena kurangnya pemahaman, sikap, dan tindakan dalam pemberian asuhan keperawatan yang sesuai dengan prosedur. Dan suatu rumah sakit diharuskan mempunyai dan melaksanakan berbagai prosedur standar perawatan, pengobatan, dan perlu ada panitia pengendalian infeksi rumah sakit (PIRS). Dikarenakan kegiatan pengendalian infeksi rumah sakit merupakan suatu keharusan untuk melindungi pasien dari kejadian infeksi dalam bentuk pencegahan. Berdasarkan hal tersebut, maka penulis tertarik untuk mengetahui perilaku perawat dalam pencegahan infeksi nosokomial di ruang Asoka 1 RSUD Dr. Pirngadi Medan tahun 2014.

\section{METODE PENELITIAN}

Jenis penelitian yang digunakan dalam penelitian ini adalah dekskriptif yang menggambarkan perilaku perawat dalam pencegahan infeksi nosokomial di RSUD Dr. Pirngadi Kota Medan. Desain penelitian cross sectional dimana variabel bebas dan terikat dilakukan pengukuran atau pengamatan pada saat bersamaan. Penelitian dilaksanakan di ruangan Asoka 1 RSUD dr. Pirngadi Kota Medan pada bulan Maret - Mei 2014. Populasi adalah keseluruhan subjek penelitian. Populasi adalah perawat yang ada di Ruang Asoka 1 RSUD Dr. Pirngadi Medan yang berjumlah 30 perawat dan seluruhnya dijadikan sampel. Data yang digunakan adalah data primer yaitu data langsung diperoleh atau diambil oleh peneliti terhadap sasaran (responden) melalui wawancara dan observasi, dan data sekunder yaitu data yang diperoleh dari Rekam Medik (medical record) RSUD dr Pingadi Medan. Analisa data dilakukan secara manual dengan melihat persentase dari tiap-tiap kategori variabel yang diukur (univariat). Analisa univariat adalah seluruh variabel diolah dengan memasukkan data dari tabel distribusi frekuensi selanjutnya menghitung proporsi.

\section{HASIL PENELITIAN DAN PEMBAHASAN}

\section{Hasil Penelitian}

Dari hasil penelitian mengenai perilaku perawat dalam pencegahan infeksi nosokomial dengan responden 30 orang diperoleh hasil berdasarkan pencegahan infeksi nosokomial baik sebanyak 8 responden $(26,7 \%)$ dan tidak baik sebanyak 22 responden (73,3\%). Tingkat pengetahuan dalam pencegahan infeksi nosokomial baik sebanyak 14 responden (46,7\%) dan cukup sebanyak 16 responden (53,3\%). Sikap responden dalam pencegahan infeksi nosokomial positif sebanyak 24 responden (80\%) dan negatif sebanyak 6 responden $(20 \%)$. Tindakan responden dalam pencegahan infeksi nosokomial dilakukan sebanyak 5 responden $(16,7 \%)$ dan tidak dilakukan sebanyak 25 responden (83,3\%).

Distribusi frekuensi pencegahan infeksi nosokomial berdasarkan pengetahuan diketahui dari 14 responden $(46,7 \%)$ dengan pengetahuan baik, sebanyak 4 responden $(50 \%)$ baik dan 10 responden $(45,5 \%)$ tidak baik dalam melakukan pencegahan infeksi nosokomial. Dari 16 responden dengan pengetahuan cukup sebanyak 4 responden $(50 \%)$ baik dan sebanyak 12 responden $(54,5 \%)$ tidak baik dalam melakukan pencegahan infeksi nosokomial.

Distribusi frekuensi pencegahan infeksi nosokomial berdasarkan sikap diketahui dari 24 
responden $(80 \%)$ dengan sikap positif, sebanyak 7 responden $(87,5 \%)$ baik dan 17 responden $(77,3 \%)$ tidak baik dalam melakukan pencegahan infeksi nosokomial. Dari 6 responden dengan sikap negatif sebanyak 1 responden $(12,5 \%)$ baik dan sebanyak 5 responden $(22,7 \%)$ tidak baik dalam melakukan pencegahan infeksi nosokomial.

Distribusi frekuensi pencegahan infeksi nosokomial berdasarkan tindakan diketahui dari 5 responden $(16,7 \%)$ melakukan tindakan, seluruhnya tidak baik dalam melakukan pencegahan infeksi nosokomial. Dari 25 responden $(83,3 \%)$ yang tidak melakukan tindakan sebanyak 8 responden $(22,7 \%)$ baik dan sebanyak 17 responden $(77,3 \%)$ tidak baik dalam melakukan tindakan pencegahan infeksi nosokomial.

\section{Pembahasan}

Berdasarkan frekuensi pengetahuan responden mayoritas berpengetahuan cukup sebanyak 16 orang $(53,3 \%)$ dari 30 jumlah responden. Dan dari tabel 4.5 distribusi frekuensi responden dalam pencegahan infeksi nosokomial berdasarkan pengetahuan dapat dilihat bahwa mayoritas responden dalam pencegahan infeksi nosokomial tidak baik memiliki tindakan cukup yaitu sebanyak 12 orang $(54,5 \%)$. Hasil penelitian ini dapat dilihat sejalan dengan teori Notoadmodjo (2003) bahwa pengetahuan sangat berpengaruh terhadap perilaku responden, semakin tinggi tingkat pengetahuan seseorang maka akan semakin baik pengetahuannya, karena pengetahuan merupakan hasil dari penginderaan terhadap suatu objek tertentu. Menurut peneliti sesuai dengan teori di atas dan hasil penelitian ini bahwa responden lebih sedikit memiliki pengetahuan baik sehingga dalam pencegahan infeksi nosokomial juga kurang maksimal. Dapat disimpulkan semakin tinggi pengetahuannya maka akan semakin mudah untuk menerima informasi dan semakin baik pengetahuan yang dimiliki sehingga pencegahan infeksi nosokomial dapat dilakukan secara maksimal.

Dari hasil penelitian didapatkan bahwa responden yang bersikap positif sebanyak 24 orang $(80 \%)$. Dan dari distribusi frekuensi responden dalam pencegahan infeksi nosokomial berdasarkan sikap dapat dilihat bahwa mayoritas responden dalam pencegahan infeksi nosokomial tidak baik memiliki sikap yang positif 17 orang $(77,3 \%)$. Menurut Notoadmodjo (2003) dalam penentuan sikap yang utuh, pengetahuan berpikir, keyakinan dan emosi memiliki peranan penting. Sikap merupakan kesiapan atau kesedian untuk bertindak dan bukan merupakan pelaksanaan motif tertentu (Teori Newcomb). Menurut peneliti sikap timbul dari pengalaman, tidak dibawa dari lahir tetapi merupakan hasil belajar karena itu sikap dapat diperteguh atau diubah karena pembentukan sikap yang paling efektif adalah dari pengalaman sendiri.

Dari hasil penelitian mayoritas tindakan tidak dilakukan yaitu sebanyak 25 orang $(83,3 \%)$. Dan dari tabel 4.7 distribusi frekuensi responden dalam pencegahan infeksi nosokomial berdasarkan tindakan bahwa mayoritas responden dalam pencegahan infeksi nosokomial tidak baik memiliki tindakan negatif yaitu 17 orang $(77,3 \%)$. Hal ini sejalan dengan teori Notoadmojdo (2007) bahwa semakin baik pengetahuan seseorang maka semakin baik pula sikap dan tindakannya. Dalam hal ini peneliti melihat bahwa pencegahan infeksi nosokomial belum maksimal karena mayoritas responden memiliki pengetahuan cukup sehingga pencegahan infeksi nosokomial masih belum baik. Menurut peneliti hal ini bisa saja disebabkan oleh kebiasaan para perawat melakukan tindakan tanpa memperhatikan kebenaran atau prosedur tindakan yang tidak sesuai.

Berdasarkan distribusi frekuansi didapatkan 22 orang $(73,3 \%)$ responden memiliki tindakan tidak dilakukan dan tindakan responden yang dilakukan hanya sebanyak 7 orang $(26,7 \%)$. Dari tabel diatas peneliti juga melihat mayoritas responden masih lebih mengikuti kebiasaan daripada prosedur yang benar, sehingga hal itu dapat meningkatkan angka kejadian infeksi nosokomial. Disamping itu peneliti juga melihat sebagian responden memang menganggap pencegahan infeksi nosokomial tersebut penting tetapi dalam pelaksanaannya terkadang responden masih melakukan tindakan yang salah. Sebagai salah satu contoh adalah mencuci tangan, responden melakukan cuci tangan sebelum dan sesudah melakukan tindakan dan menggunakan antiseptik tetapi tidak sesuai dengan prosedur cara mencuci tangan. Pernyataan di atas tidak sejalan dengan pendapat Larson (2005) yang mengatakan bahwa tehnik yang paling penting dalam pencegahan dan penularan infeksi adalah mencuci tangan dengan cara menggosok tangan dengan antiseptik secara bersama pada seluruh permukaan kulit, kemudian dibilas dibawah air yang mengalir, hal tersebut dikarenakan dapat menurunkan jumlah mikroorganisme pada tangan dan mencegah penyebaran mikroorganisme ke area yang tidak terkontaminasi. Hal tersebut sejalan dengan hasil penelitian Rosita (2010) tentang hubungan karateristik perawat dengan tingkat kepatuhan perawat melakukan cuci tangan di Rumah Sakit Columbia Asia Medan menunjukkan adanya hubungan yang bermakna antara tingkat pengetahuan mengenai cuci tangan dengan tingkat kepatuhan melakukan cuci tangan $(\mathrm{p}=0,02)$, ada hubungan yang bermakna antara tingkat pendidikan dengan tingkat kepatuhan melakukan cuci tangan ( $\mathrm{p}=$ 0,04 ), ada hubungan yang bermakna antara umur dengan tingkat kepatuhan perawat melakukan cuci tangan $(\mathrm{p}=0,02)$, ada hubungan yang bermakna antara lama bekerja dengan tingkat kepatuhan melakukan cuci tangan $(\mathrm{p}=0,04)$ di Rumah Sakit Columbia Asia Medan.

\section{KESIMPULAN DAN SARAN}

\section{Kesimpulan}

Berdasarkan hasil penelitian dan pembahasan yang dilakukan oleh peneliti terhadap perilaku perawat dalam pencegahan infeksi nosokomial di Ruang Asoka 
1 dengan jumlah responden 30 orang dapat disimpulkan mayoritas responden tidak baik dalam melakukan pencegahan terhadap infeksi nosokomial yaitu sebanyak 22 responden $(73,3 \%)$ tetapi responden memiliki pengetahuan yang cukup sebanyak 16 orang $(53,3 \%)$, sikap responden positif sebanyak 24 orang $(80 \%)$ tetapi mayoritas responden tidak melakukan tindakan pencegahan sebanyak 25 orang $(83,3 \%)$.

\section{Saran}

Disarankan kepda RSUD Pirngadi Medan menempelkan poster-poster mengenai proteksi diri di setiap ruangan guna menambah wawasan pasien, keluarga pasien dan untuk mengingatkan petugas. Kepada seluruh perawat ruangan Asoka 1 RSUD Pirngadi untuk lebih meningkatkan pelayanan kesehatan khususnya tentang pencegahan infeksi nosokomial dengan meningkatkan atau memperdalam lagi pengetahuan tentang infeksi nosokomial. Hasil penelitian ini diharapkan dapat menambah wawasan bagi pendidikan keperawatan agar memiliki keterampilan melakukan tindakan pencegahan infeksi nosokomial sehingga bersikap yang baik dalam melakukan tindakan.

\section{DAFTAR PUSTAKA}

Arikunto. 2010. Metode Penelitian Pendidikan. Bandung : Alfabeta

Bea, Betty Septiari. 2012. Infeksi Nosokomial. Yogyakarta : Nuha Medika

Brunner \& Suddarth. 2008. Buku Ajar Keperawatan Medikal Bedah Volume 3 Jakarta : EGC

Darmadi, 2008. Infeksi Nosokomial. Cetakan ke- I, Jakarta Departemen Kesehatan, 1998. Peran Dan Fungsi Perawat, diunduh Januari 2014, from http://www.departemenkesehatan. ac.id
Notoadmodjo, Soekidjo. 2010. Ilmu Perilaku Kesehatan. Jakarta : Renika Cipta

Notoadmodjo, Soekidjo. 2005. Metodologi Penelitian Kesehatan. Jakarta: Renika Cipta

Notoadmodjo, Soekidjo. 2012. Promosi Kesehatan Dan Perilaku Kesehatan. Jakarta : EGC

Nurseha, Djafar. 2011. Pengembangan Tindakan Pencegahan Infeksi Nosokomial Oleh Perawat Di Rumah Sakit Berbasis Health Belief Model, diunduh Januari, from http://Healthbeliefmodel.co.id

Rosita \& Natalina. 2010. Hubungan Karakteristik Perawat Dengan Tingkat Kepatuhan Perawat Melakukan Cuci Tangan di Rumah Sakit Columbia Asia Medan, diunduh pada Januari 2014, from http:// www.jurnal.uda.ac.id

Swearing, B C. (2003). Perawatan Medikal Bedah (Infeksi dalam suatu luka). Bandung: Yayasan IAPK Pajajaran.

Tietjen, Linda. 2004. Penyebab Infeksi Nosokomial, diunduh januari 2014, from http.://www.grahac.endikin.co.id

Wikansari dkk. 2012. Pemeriksaan Total Kuman Udara Dan Staphyloccus Aureus Di Ruang Rawat Inap Rumah Sakit X Kota Semarang, diunduh pada Januari 2014, from http://ejournls1.ac.id

Zulkarnain, Iskandar. 2006. Ilmu Penyakit Dalam Edisi 5. Jakarta : Fakultas Kedokteran Universitas Indonesia. 